\title{
18. PETROGRAPHY AND K-Ar DATING OF THE MAZAGAN GRANODIORITE, DEEP SEA DRILLING PROJECT LEG 79, HOLES 544A AND 547B1
}

\author{
H. Kreuzer, P. Müller, and G. Wissmann, Bundesanstalt für Geowissenschaften und Rohstoffe \\ and \\ T. Reinecke, Mineralogisch-Petrographisches Institut der Technischen Universität Braunschweig ${ }^{2}$
}

\begin{abstract}
Gneissic granodiorite was recovered by drilling at the base of the Mazagan escarpment, $100 \mathrm{~km}$ west of the Casablanca, Morocco, at $4000 \mathrm{~m}$ water depth. Coarse, predeformative muscovite yielded dates of $\sim 515 \mathrm{Ma}$, fine-grained muscovite of $\sim 455 \mathrm{Ma}$, biotite $\sim 360$ and $335 \mathrm{Ma}$, and feldspar $\sim 315 \mathrm{Ma}$. These dates are tentatively correlated with the microscopic results. We assume a minimum age of middle Cambrian for the granodiorite, an Ordovician deformation and mylonitization, and a Late Carboniferous overprint under upper greenschist facies conditions.
\end{abstract}

\section{INTRODUCTION}

At the base of the slope leading up to the Mazagan Plateau, $100 \mathrm{~km}$ west off Casablanca, Morocco, piston cores (Vema 30) and dredge samples (Valdivia 79) have traced a mylonitic "granite." A geoseismic section shows an up-faulted wedge with a thin sedimentary cover (Wissmann and von Rad, 1979, fig. 5; Winterer and Hinz, this volume). $\mathrm{K}-\mathrm{Ar}$ dates on muscovite from one piston core and one dredge sample (Table 2) were discordant and considerably older than mineral dates from the Moroccan mainland, which recorded mainly late Paleozoic events (Michard and Piqué, 1980). We hoped that the DSDP core material would be suitable for a $\mathrm{Rb}-\mathrm{Sr}$ wholerock isochron, but core recovery was poor and the $\mathrm{Rb}-\mathrm{Sr}$ ratio of the granodiorite was low. Therefore, only $\mathrm{K}-\mathrm{Ar}$ mineral dating was attempted on this new material.

\section{PETROGRAPHY}

We investigated ten samples by thin sections (Vema $30-225$ and 30-227; Valdivia 79-96 $\mathrm{KD} / 1$ to $\mathrm{KD} / 4$; DSDP 544A-27-1, 19-28 $\mathrm{cm}$ and $37-42 \mathrm{~cm}, 544 \mathrm{~A}-28-1,5-13$ $\mathrm{cm}$, and 547B-H3, CC, 18-22 cm). The sampling locations are shown in Figure 1. All samples represent the same granodioritic gneiss (or gneissic granodiorite). They consist of rather coarse plagioclase, potassium feldspar, quartz, and some biotite and muscovite of minor grainsize within a very fine-grained mylonitic ground mass. The feldspar grains are bent and fractured. Plagioclase is clouded by masses of very fine-grained epidote and contains traces of secondary greenish biotite. The turbid potassium feldspar is perthitic. Under crossed nicols, the coarse patches of quartz reveal severe fracturing and recrystallization. Medium-grained biotite of dark reddish-brown color and medium-grained muscovite aggre-

\footnotetext{
${ }^{1}$ Hinz, K., Winterer, E. L., et al., Init. Repts. DSDP, 79: Washington (U.S. Govt, Printing Office).

2 Addresses: (Kreuzer, Müller, Wissmann) Bundesanstalt für Geowissenschaften und Rohstoffe, Postfach 510153, D-3000, Hannover 51, Federal Republic of Germany; (Reinecke) Mineralogisch-Petrographisches Institut der Technischen Universităt Braunschweig. Postfach 3329, D-3300, Braunschweig. Federal Republic of Germany.
}

gates are bent and sheared. Biotite is surrounded by some fine-grained intergrowths of muscovite and hematite and by an intergrowth of greenish secondary biotite with quartz. Accessories (apatite, zircon, and brownish epidote with allanite cores) are concentrated in the primary mica aggregates (see Plate 1).

The mylonitic groundmass consists of quartz, some feldspar, sericitic muscovite, greenish secondary biotite, and considerable amounts of an epidote mineral. The epidote mineral shows a faint brown color and has a high birefringence.

Except for the fine-grained secondary muscovite, biotite, and epidote, the only mineral that was not affected by deformation is a clear microcline accompanying or replacing turbid potassium feldspar to varying degrees in the ten thin sections. The mineral assemblage of late syntectonic to posttectonic origin includes microcline, albite, plagioclase, muscovite, secondary biotite, and epidote. This is an indication of a prograde metamorphism of upper greenschist facies conditions. Temperature was certainly high enough to reset the K-Ar dates of primary biotite but probably not high enough to affect the $\mathrm{K}-\mathrm{Ar}$ date of the primary (coarse) muscovite.

The chemical analysis of the composite Sample 544A$27-1,37-42 \mathrm{~cm}+544 \mathrm{~A}-28-1,5-13 \mathrm{~cm}$ (Table 1A) is similar to that of Sample 544A-26-1, 32-36 cm given by Sachtleben and Schmincke (this volume). The calculated plutonic modes (Müller, 1982) of our sample (Table 1C) and of the five samples analyzed by Sachtleben and Schmincke all plot into the granodioritic field of the Q-A-P diagram of Streckeisen (1973) (Fig. 2).

The second analysis in Table 1 is of mica-depleted material from Sample 544A-27-1, 19-28 cm. The major deviation from the whole-rock analysis is a higher content of $\mathrm{CaO}$ and $\mathrm{Na}_{2} \mathrm{O}$ and a lower content of $\mathrm{Fe}_{2} \mathrm{O}_{3}$, $\mathrm{MgO}$ and $\mathrm{K}_{2} \mathrm{O}$. The CIPW norm of this feldspar-quartz concentrate gives normative contents of wollastonite and diopside instead of corundum (Table 1B). In order to verify the nature of the cloudy material in plagioclase, an epinorm was computed (Table 1C). Clouding by sericitic mica can be excluded due to the absence of 


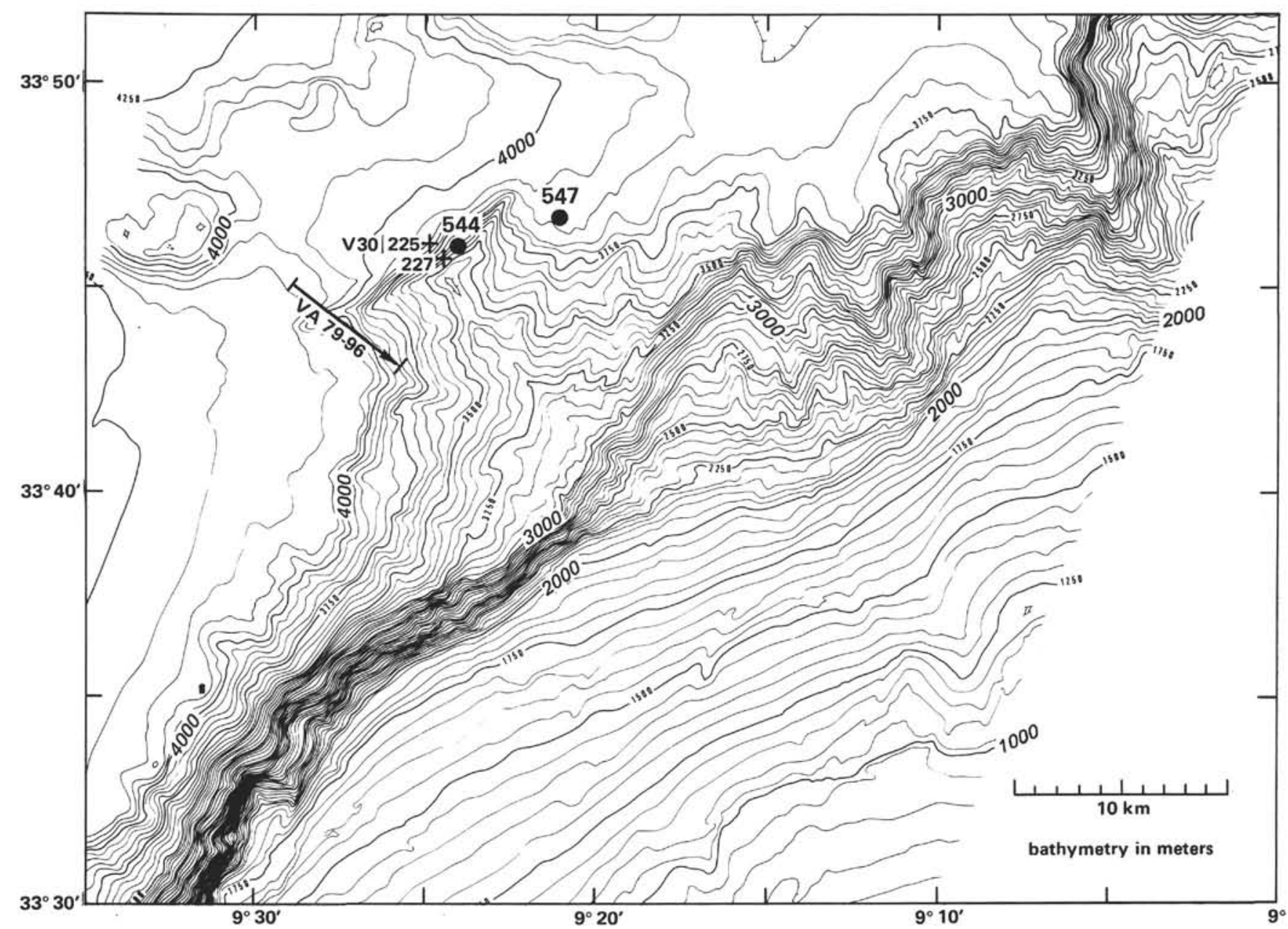

Figure 1. Bathymetric map of the Mazagan escarpment. Granodiorite mylonite was recovered by Valdivia 79-96 dredge course (arrow), Vema 30 piston cores (crosses), and by DSDP Holes 544A and 547B (circles). Source of seabeam bathymetry: Auzende et al., this volume.

appropriate normative corundum. The epinorm of the feldspar-quartz concentrate yields $10 \%$ of epidote and some biotite $(0.3 \%)$ (expressed in Niggli-Barth's 1-cation norm) (Shaw, 1969). The anorthite content of the remaining plagioclase is very low (about $2 \%$ ). Clouding of plagioclase by epidote and accompanying traces of secondary biotite could be ascertained microscopically. The low anorthite content of the plagioclases could not be verified by microscopic methods due to severe clouding.

\section{K-Ar DATING}

\section{Sample Preparation and Analytical Procedures}

A piston core sample of $24 \mathrm{~g}$ and a dredge sample of $8 \mathrm{~g}$ were carefully disaggregated step by step in a presser and mica flakes were separated with needle and tweezers. The DSDP sample of $130 \mathrm{~g}$ was crushed, ground in a cylinder mill, and micas and feldspar were separated by a Frantz isodynamic magnetic separator. Potassium was determined by flame photometry and argon by conventional total fusion mass spectrometric isotope-dilution analysis (Seidel et al., 1982). The IUGS recommended constants were used (Steiger and Jäger, 1977). The results are given in Table 2 .

\section{Discussion}

The mineral dates of the three samples of Mazagan granodiorite are highly discordant. They range from about $500 \mathrm{Ma}$ to $300 \mathrm{Ma}$ (Fig. 3). This range is far more than can be explained by analytical and splitting uncertainties and is clearly of geological significance. However, a detailed interpretation of discordant results on only three samples, which moreover were unusually small, must be regarded with caution. We tentatively correlate the mineral dates with the sequence of crystallizations and deformation deduced from the microscopic investigation of the thin sections. The petrographic evidence leads us to assume three events (1) an intrusion, relics of which are the coarse-grained, deformed muscovites; (2) a deformation, which caused the mylonitization and partial recrystallization, especially of fine-grained muscovite; and (3) a post-deformative partial recrystallization, which is indicated by the epidote minerals and some clear K-feldspars, but also could be related to the event that caused the deformation.

The two coarse fractions of muscovite yielded similar dates of $519 \pm 21$ and $515 \pm 8 \mathrm{Ma}$, respectively. We know that muscovites seldom have high concentrations 
Table 1. Composition of the Mazagan granodiorite.

A. X-ray fluorescence analysis

\begin{tabular}{lrr} 
& Rock & \multicolumn{1}{c}{ F-qtz } \\
\hline \multicolumn{3}{l}{ Major elements (wt.\%) } \\
$\mathrm{SiO}_{2}$ & 73.18 & 73.20 \\
$\mathrm{TiO}_{2}$ & 0.10 & 0.02 \\
$\mathrm{Al}_{2} \mathrm{O}_{3}$ & 14.82 & 14.02 \\
$\mathrm{Fe}_{2} \mathrm{O}_{3}$ & 1.10 & 0.27 \\
$\mathrm{MnO}$ & 0.03 & 0.01 \\
$\mathrm{MgO}$ & 0.26 & 0.09 \\
$\mathrm{CaO}$ & 1.63 & 2.69 \\
$\mathrm{Na} 2 \mathrm{O}$ & 3.99 & 4.52 \\
$\mathrm{~K}_{2} \mathrm{O}$ & 3.40 & 2.93 \\
$\mathrm{P}_{2} \mathrm{O}_{5}$ & 0.03 & 0.02 \\
$\mathrm{LOI}$ & 0.63 & 1.50 \\
$\mathrm{Sum}$ & 99.17 & 99.27
\end{tabular}

Trace elements (ppm)

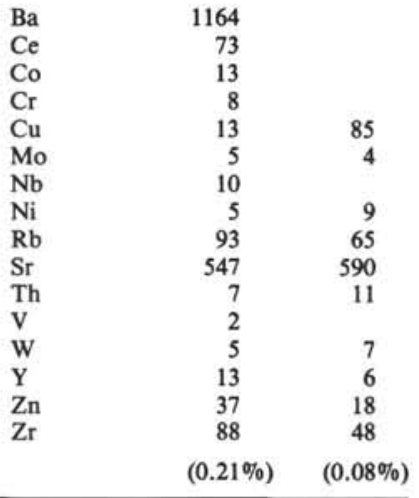

B. $\mathrm{Cl}_{\text {'W }}$ norm (wt.\%)

\begin{tabular}{|c|c|c|}
\hline Q & 32.24 & 30.46 \\
\hline $\mathrm{C}$ & 1.70 & \\
\hline Or & 20.20 & 17.37 \\
\hline $\mathrm{Ab}$ & 33.84 & 38.24 \\
\hline An & 8.34 & 9.30 \\
\hline Wo & & 1.08 \\
\hline $\mathrm{Di}$ & & 1.30 \\
\hline $\mathrm{Hy}$ & 2.36 & \\
\hline Ap & 0.07 & 0.05 \\
\hline Il & 0.19 & 0.04 \\
\hline $\mathrm{Zr}$ & 0.01 & 0.01 \\
\hline \multicolumn{3}{|c|}{$\begin{array}{l}\text { C. Calculated mode } \\
\text { (equivalence } \%^{\mathrm{a}} \text { ) }\end{array}$} \\
\hline Quartz & 31.47 & 29.45 \\
\hline Orthoclase & 14.92 & 17.51 \\
\hline Albite & 36.52 & 41.52 \\
\hline Anorthite & 8.46 & 0.71 \\
\hline Muscovite & 5.93 & \\
\hline Biotite & 2.20 & 0.33 \\
\hline Epidote & & 10.40 \\
\hline Apatite & 0.06 & 0.04 \\
\hline Ilmenite & 0.14 & 0.03 \\
\hline Magnetite & 0.28 & \\
\hline Zircon & 0.01 & 0.01 \\
\hline
\end{tabular}

Note: Li-tetraborate glass disks, Philips PW 1450-spectrometer; analysis by J. Lodziak and D. Requard. Rock = composite Sample DSDP 544A-27-1, $37-42 \mathrm{~cm}+544 \mathrm{~A}-28-1,5-13 \mathrm{~cm}$. F-qtz $=$ feldspar-quartz concentrate, micadepleted DSDP 544A-27-1, 19-28 cm.

a Niggli-Barth's 1-cation norm. For rock, the plutonic norm is given, for $f-q t z$, the epinorm.

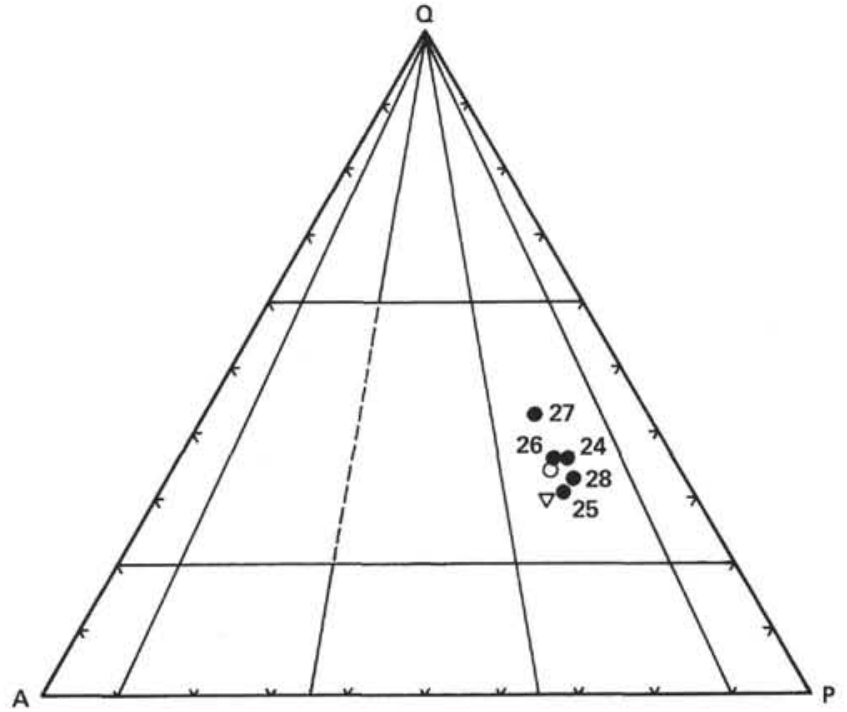

Figure 2. Q-A-P diagram of the Mazagan granodiorite of DSDP Hole 544A. Dots, labeled with core numbers, are from analyses by Sachtleben and Schmincke (this volume). Circle = composite sample Cores $27+28$; triangle $=$ feldspar-quartz concentrate from Core 27. Calculation of the plutonic norm according to Müller, 1982.

of excess argon. We can therefore assume that the date of about $515 \mathrm{Ma}$ is geologically meaningful and that the intrusion of the Mazagan granodiorite is, at least, of middle Cambrian age according to "the Phanerozoic time scale in 1981" (Odin et al., 1982).

The coarse grain-size fraction of muscovites from the DSDP sample has an unusually high concentration of atmospheric argon. It is more than twice the amount observed in the fine fraction of muscovite, in biotite, or in feldspar, all of which are within the usually observed ranges. Therefore, the high concentration in the coarse fraction of muscovite cannot be ascribed to a contamination by these minerals but is characteristic for the coarse muscovite of DSDP core Sample 544A-27-1, 19-28 cm. The finer fractions of muscovite yielded dates around $455 \mathrm{Ma}$, a value significantly less than that for the coarser fractions. Contamination by abraded parts of the coarser muscovite is judged to be insignificant because the fine fraction of muscovite from the DSDP sample shows no unusually elevated atmospheric argon content.

Two simple hypotheses explain the different dates for coarse and fine muscovite:

1. The middle Ordovician date (time scale from Odin et al., 1982) is real and probably is the time of deformation and mylonitization.

2. The muscovite dates are mixed ages resulting from partial losses of radiogenic argon, higher in the finer than in the coarser grain-size fractions. The initial age of the Mazagan granodiorite would be older than 515 $\mathrm{Ma}$, and the rejuvenation would be either Late Devonian/Early Carboniferous (i.e., Acadian) as tentatively suggested from the biotite dates or Late Carboniferous as indicated by the feldspar dates.

We prefer the first explanation because of the internal consistency of the dates on the coarse, premylonitic mus- 
Table 2. $\mathrm{K}$ and $\mathrm{Ar}$ determinations, mean values, and $\mathrm{K}-\mathrm{Ar}$ dates of the Mazagan granodiorite.

\begin{tabular}{|c|c|c|c|c|c|c|}
\hline \multirow{2}{*}{$\begin{array}{l}\text { Material } \\
\text { (size- } \\
\text { fraction } \\
{[\mu \mathrm{m}] \text { in }} \\
\text { parentheses) }\end{array}$} & \multirow[b]{2}{*}{$\begin{array}{l}\text { K-Ar } \\
\text { date } \\
\text { (Ma) }\end{array}$} & \multicolumn{3}{|c|}{ Argon $^{a}$} & \multicolumn{2}{|c|}{ Potassium } \\
\hline & & $\begin{array}{c}\text { Charge } \\
\text { (mg) }\end{array}$ & $\begin{array}{l}\text { Radiogenic } \\
\text { (nl/g)STP }\end{array}$ & $\begin{array}{l}\text { Atmospheric } \\
(\mathrm{nl} / \mathrm{g}) \text { STP }\end{array}$ & $\begin{array}{c}\text { Charge } \\
\text { (mg) }\end{array}$ & $\begin{array}{c}\mathbf{K} \\
\text { (wt.\%) }\end{array}$ \\
\hline \multicolumn{7}{|c|}{ Piston Core Sample Vema 30-225 } \\
\hline \multirow[t]{2}{*}{$\begin{array}{l}\text { Rock, } \\
\quad \text { depleted } \\
\text { in mica } \\
(400-200)\end{array}$} & & 1350 & $\begin{array}{r}36.17 \\
(20)\end{array}$ & $\begin{array}{l}2.24 \\
\text { (5) }\end{array}$ & $\begin{array}{l}150 \\
150^{\mathrm{b}}\end{array}$ & $\begin{array}{r}2.702 \\
(16) \\
2.631 \\
(15) \\
\end{array}$ \\
\hline & $\begin{array}{r}319 \\
8\end{array}$ & & $\begin{array}{r}36.17 \\
45\end{array}$ & & & $\begin{array}{r}2.667 \\
70\end{array}$ \\
\hline \multirow[t]{2}{*}{$\begin{array}{l}\text { Coarse } \\
\text { muscovite } \\
\text { (hand-picked, } \\
\text { not pure) }\end{array}$} & & $\begin{array}{l}28.6 \\
23.3\end{array}$ & $\begin{array}{c}201.0 \\
(1.2) \\
205.5 \\
(1.1)\end{array}$ & $\begin{array}{c}1.46 \\
(47)\end{array}$ & $\begin{array}{l}11 \\
11\end{array}$ & $\begin{array}{c}8.51 \\
(45) \\
8.87 \\
(45) \\
\end{array}$ \\
\hline & $\begin{array}{r}519 \\
21\end{array}$ & & $\begin{array}{r}203.2 \\
4.5\end{array}$ & & & $\begin{array}{r}8.69 \\
36\end{array}$ \\
\hline \multicolumn{7}{|c|}{ Dredge Sample Valdivia $79-96 \mathrm{KD} / 4$} \\
\hline \multirow[t]{2}{*}{$\begin{array}{l}\text { Rock, } \\
\quad \text { depleted } \\
\text { in mica } \\
(400-200)\end{array}$} & & 425 & $\begin{array}{r}33.54 \\
(18)\end{array}$ & $\begin{array}{r}1.453 \\
(49)\end{array}$ & $\begin{array}{l}150 \\
150\end{array}$ & $\begin{array}{r}2.538 \\
(15) \\
2.477 \\
(15)\end{array}$ \\
\hline & $\begin{array}{r}315 \\
10\end{array}$ & & $\begin{array}{r}33.54 \\
80\end{array}$ & & $\cdot$ & $\begin{array}{r}2.507 \\
60\end{array}$ \\
\hline \multirow[t]{2}{*}{$\begin{array}{l}\text { Fine } \\
\text { muscovite } \\
\text { (hand-picked } \\
\text { not pure) }\end{array}$} & & $\begin{array}{l}5.1 \\
5.0\end{array}$ & $\begin{array}{c}150.4 \\
(1.5) \\
143.3 \\
(1.4)\end{array}$ & $\begin{array}{l}3.5 \\
(1.8) \\
0.4 \\
(1.4)\end{array}$ & 10 & $\begin{array}{r}7.517 \\
(40)\end{array}$ \\
\hline & $\begin{array}{r}444 \\
27\end{array}$ & & $\begin{array}{r}147 \\
7\end{array}$ & $\begin{array}{l}2 \\
3\end{array}$ & & $\begin{array}{l}7.52 \\
36\end{array}$ \\
\hline
\end{tabular}

DSDP Leg 79, Hole 544A, Core 27, Section 1, 19-28 cm

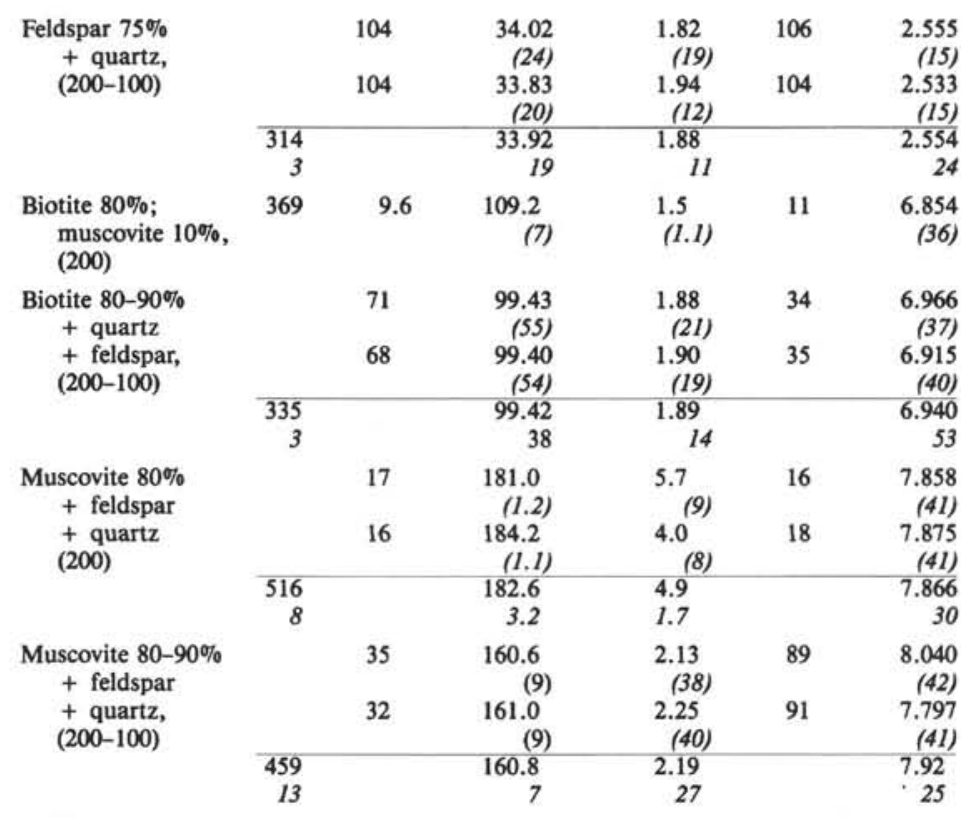

Note: Estimate of uncertainty at the $95 \%$ level of confidence is given in italics. Uncertainties in parentheses are merely analytical, not including sample inhomogeneity. The latter is covered by the difference of duplicate determinations. Above the rule are analytical results; below are average values - the adopted values and calculated K-Ar data, respectively. IUGS-recommended constants used (Steiger and Jäger, 1977):

$$
\begin{aligned}
& \lambda_{e}+\lambda_{e}^{\prime}=0.58110^{-10} a_{a}^{-1}, \quad 40_{\mathrm{Ar}} / 36_{\mathrm{Ar}}=295.5 \text {, } \\
& \lambda_{\bar{\beta}}=4.96210^{-10} \mathrm{a}-1,
\end{aligned}
$$

For results on standard minerals, see Odin, 1982.

${ }^{a}$ Nanoliter $/ g$ at standard temperature and pressure.

b From $500 \mathrm{mg}$ ground material.

c From $425 \mathrm{mg}$ ground material.

d This amount constituted one quarter of Section 1. 


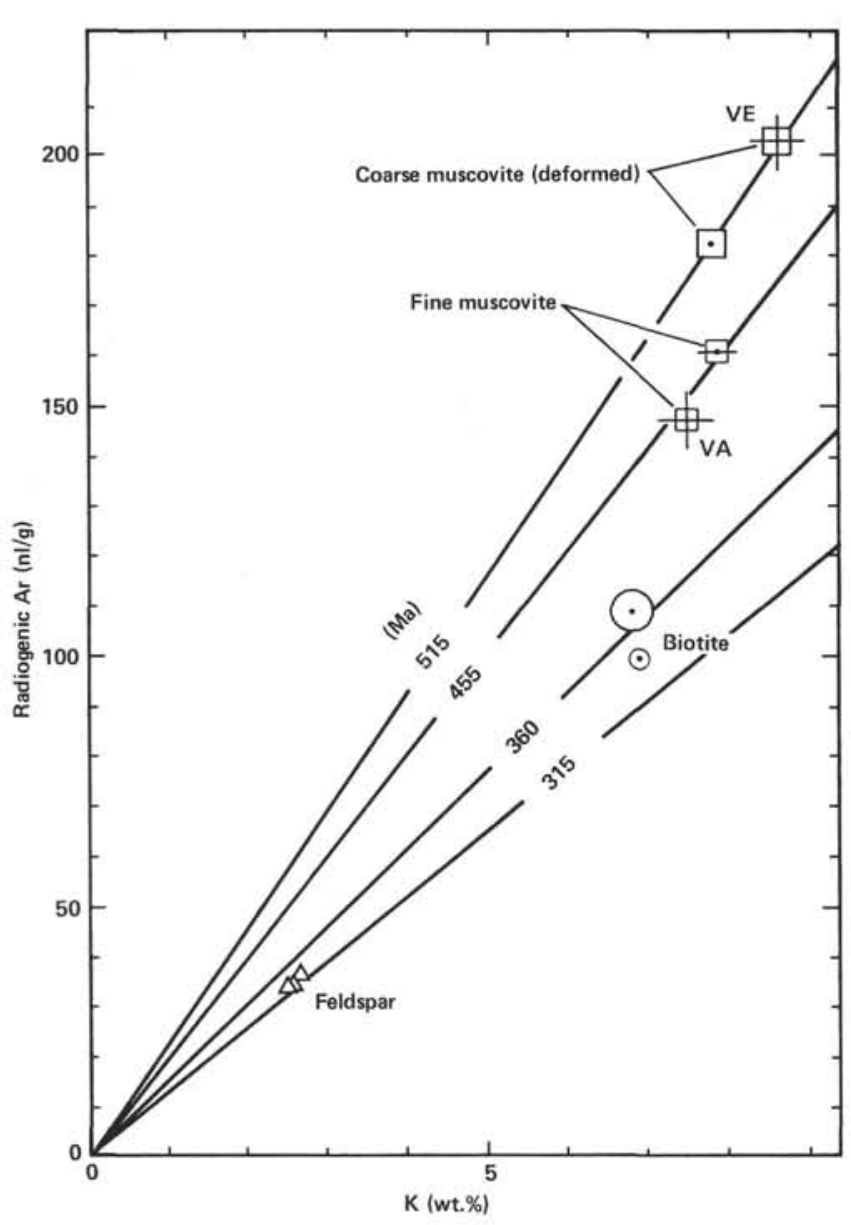

Figure 3. Diagram of radiogenic argon versus potassium for mineral concentrates from Mazagan granodiorite. There is no correlation with a positive intercept at the argon axis, i.e., no indication for excess radiogenic argon from this plot. Reference isochrons are given for the means values of coarse muscovites (minimum age of the intrusion), for the fine muscovites (probably time of deformation), for the biotites (mixed ages), and for the feldspars (indication for a Late Carboniferous weak overprint). VE = coarse muscovite from the Vema piston core, VA = fine muscovite from the Valdivia dredge sample. The other two muscovites, the biotites, and one of the three feldspar concentrates are from Hole 544A, Core 27 , Sec. $1,19-28 \mathrm{~cm}$.

covites as well as that of the dates on the fine, recrystallized muscovites, each from two samples from different locations.

The dates on the two grain-size fractions of biotite from the DSDP sample are analytically different from one another. By taking into account contaminations, i.e., muscovite with an older date in the coarse fraction, and feldspar with a younger date in the fine fraction, the dates of the pure biotites would be closer together. But they remain discordant with values of about $360 \pm$ 10 and $336 \pm 4 \mathrm{Ma}$, respectively. The concentrate of feldspar from the DSDP sample as well as the wholerock fractions, depleted in micas, from the two other samples appear to be similar in the mineral phase that dominates the $\mathrm{K}-\mathrm{Ar}$ system. We can assume that the dates are essentially governed by the microcline. The dates of $314 \pm 3,319 \pm 8$, and $315 \pm 10 \mathrm{Ma}$ are regarded as concordant. However, perthitic microcline is known to be an unreliable chronometer with variable losses of radiogenic argon. Neither biotite nor feldspar allow a definitive dating. However, both point to a post-Devonian (i.e., Variscan), probably a Late Carboniferous, rejuvenation which we ascribe to the late metamorphic influences of greenschist facies conditions as indicated by epidote and the recrystallization of feldspar.

\section{Comparisons with Adjacent Areas}

At Cape Mazagan (El Jadida), $100 \mathrm{~km}$ southeast of the outcrops of the offshore Mazagan granodiorite, there are outcrops of rhyolite overlying presumably early Cambrian sedimentary rocks. This is evidence that magmatic rocks, at least as old as Cambrian, are present in the vicinity onshore (Gigout, 1965). To the south of Cape Mazagan, in the Doukkala Basin, a Silurian-Devonian succession overlies tectonized Cambro-Ordovician schists demonstrating the existence of an Ordovician deformative event (Barbu, 1977). An event of roughly the same age is also recorded to the north: In the Rabat-Tiflis zone, the thick sequence of flysch-like sediments of the Bou-Regreg formation of presumably Cambrian age was folded and metamorphosed before Late Ordovician. The event is followed by the Rabat-Tiflis granite which is $430 \mathrm{Ma}$ according to a $\mathrm{Rb}-\mathrm{Sr}$ isochron of one muscovite, one biotite, and eight whole-rock samples (Charlot et al., 1973, recalculated; Piqué, 1982).

Schenk (1980) pointed out that the lower part of the Meguma formation of Nova Scotia is similar in lithology, style of sedimentation, and age as the Moroccan Bou-Regreg formation, and Wissmann et al. (1982) speculated that the Mazagan granodiorite could belong to the source region of the Meguma formation. But there are facts which do not fit with these hypotheses. For example, there is no trace of an Ordovician metamorphic event in the Meguma formation. Furthermore, the Devonian event that affected the Meguma of Nova Scotia is only faintly indicated in Morocco by redbeds.

\section{ACKNOWLEDGMENTS}

We are indebted to E. L. Winterer and C. J. D. Adams for critically reading the manuscript and improving our English. W. B. F. Ryan provided the two Vema piston cores for a previous study (Wissmann and von Rad, 1979). H. Klappert, M. Metz, and L. Thieswald performed the argon analyses and H. Klappert and G. Stövesand the potassium determinations.

\section{REFERENCES}

Barbu, A., 1977. Le concept de zone pétrolière potentielle dans l'exploration du bassin des Doukkala (Maroc occidental). Min. Géol., 42:49-57.

Charlot, R., Rhalib, M. and Tisserant, D., 1973. Étude géochronologique préliminaire des granites de la région de Rabat-Tiflet (Maroc occidentale). Notes Service Géologique Maroc, 33(no. 249):55-57.

Gigout, M., 1965. Carte géologique de la Meseta entre Settat et Mazagan (El Jadida) (Doukkala et Chaola occidentale)-notice explicative. Éditions du Service Géologique du Maroc: Rabat (Royaume du Maroc, Direction des Mines et de la Géologie, Division de la Géologie).

Michard, A., and Piqué, A., 1980. The Variscan belt in Morocco: Structure and developmental model. In Wones, D. R. (Ed.), The Caledonides in the USA, Proc. IGCP project 27, Blacksburg, Va., Sept., 1979. Univ. Va. Geol. Mem., 2:317-322.

Müller, P., 1982. Von der CIPW-Norm ausgehende Berechnung von Mineralbeständen magmatischer Gesteine in Analogie zu der Mo- 
dalzusammensetzung plutonischer and vulkanischer Gesteine. Geol. Jahrb., D 55:3-41.

Odin, G. S., 1982. Interlaboratory standards for dating purposes. In Odin, G. S. (Ed.), Numerical Dating in Stratigraphy: Chichester (John Wiley), pp. 123-150.

Odin, G. S., Curry, D., Gale, N. H., and Kennedy, W. J., 1982. The Phanerozoic time scale in 1981. In Odin, G. S. (Ed.), Numerical Dating in Stratigraphy: Chichester (John Wiley), pp. 957-960.

Piqué, A., 1982. La zone de Rabat-Tiflet (Meseta marocaine septentrionale). Sa place dans l'ensemble des noyaux paléozoiques de la Méditerranée occidentale. C. R. Séances Acad. Sci. Paris, 295, sér. II:263-266.

Schenk, P. E., 1980. Paleogeographic implications of the Meguma Group, Nova Scotia, - a chip of Africa? In Wones, D. R. (Ed.), The Caledonides in the USA, Proc. IGCP project 27, Blacksburg, Va., Sept., 1979. Univ. Va. Geol. Mem., 2:27-30.

Shaw, D. M., 1969. Evaluation of data. In Wedepohl, K. H. (Ed.), Handbook of Geochemistry I: Berlin (Springer Verlag), pp. 324-375.
Seidel, E., Kreuzer, H., and Harre, W., 1982. A late Oligocene/early Miocene high pressure belt in the external Hellenides. Geol. Jahrb., E 23:165-206.

Steiger, R. H., and Jäger, E., 1977. Subcommission on Geology: Convention on the use of decay constants in geo- and cosmochronology. Earth Planet. Sci. Lett., 36:359-362.

Streckeisen, A., 1973. Classification and nomenclature of plutonic rocks, recommendations by the I.U.G.S. subcommission on the systematics of igneous rocks. N. Jahrb. Mineral., Abh., 4:149-164.

Wissmann, G., Müller, P., Kreuzer, H., Harre, W., and Reinecke, T., 1982. Mazagan granite (off Morocco): the source of Meguma graywacke (N.S.)? 42. Jahrestagung Deutsche geophysikalische Gesellschaft, Hannover, March 30-April 4, 91. (Abstract)

Wissmann, G., and von Rad, U., 1979. Seismic structure, continental basement, and Mesozoic sediments from the Mazagan Plateau off Morocco. Meteor Forschungs-Ergebnisse C 31:1-20.

Date of Initial Receipt: January 1, 1983

Date of Acceptance: July 27, 1983 

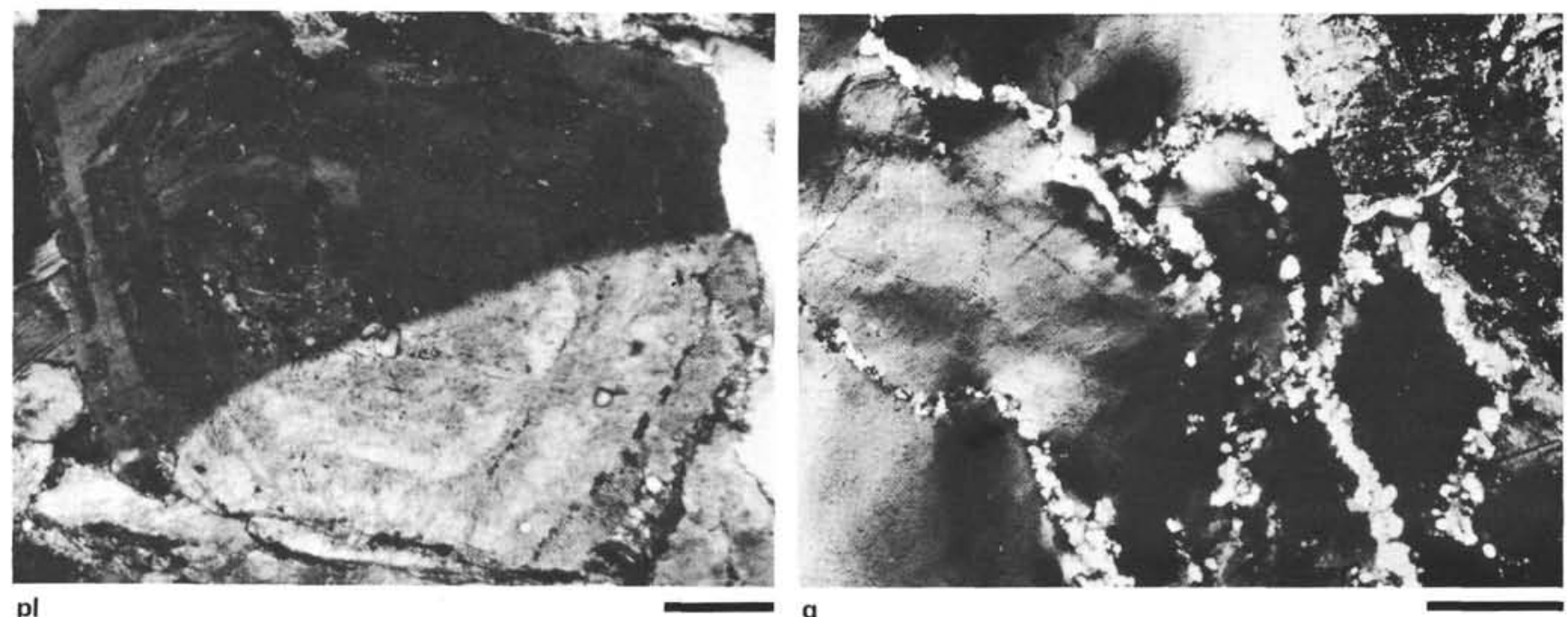

pl

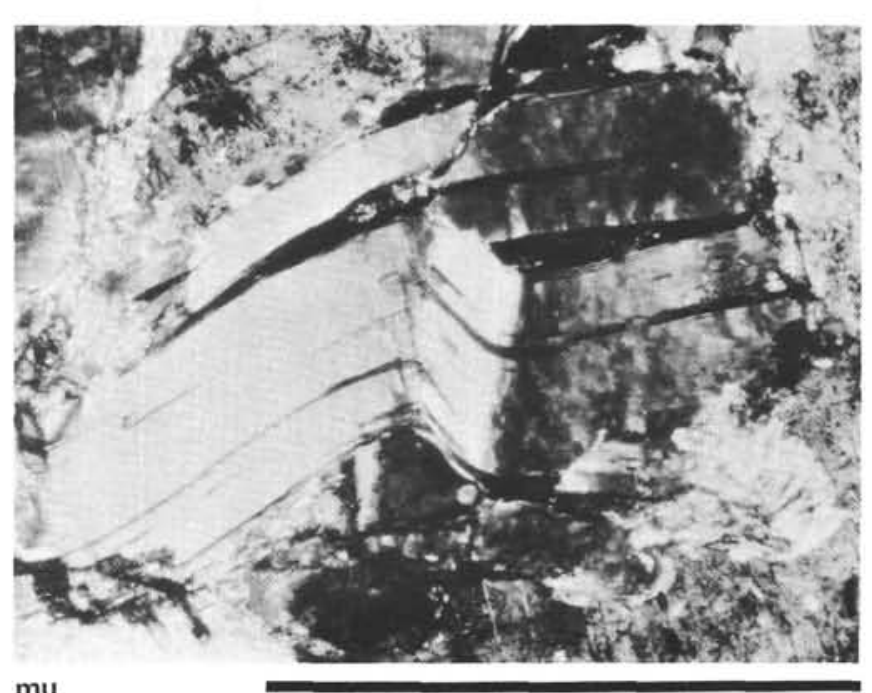

bi

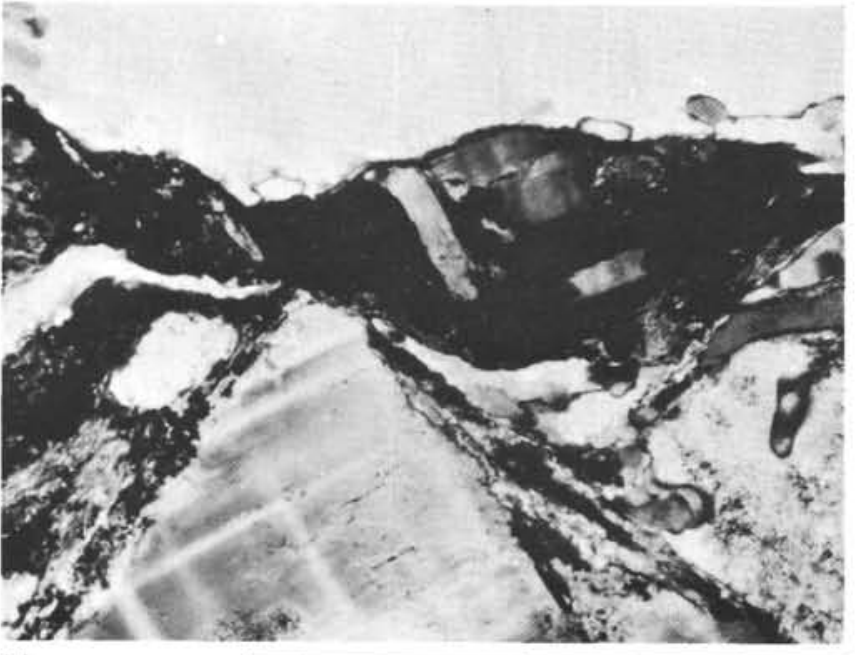

mu

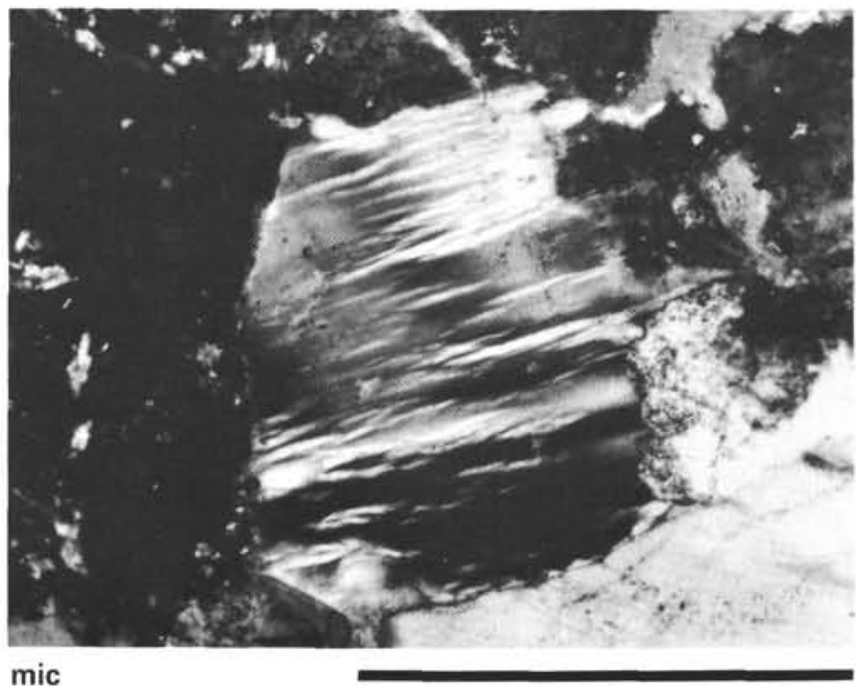

Plate 1. Photographs of thin sections DS 27726 of Sample 544A-27-1, 19-28 cm. Scale $=0.5 \mathrm{~mm}$. Upper 4 figures, deformed premylonitic minerals: pl, turbid plagioclase; q, quartz with mylonitic rims; bi, biotite with crossing secondary muscovite; mu, bent muscovite. Lower figure: mic, postdeformative microcline. 